\title{
IMPLEMENTASI ISLAMIC CORPORATE SOCIAL RESPONSIBILITY PT. SEMEN INDONESIA')
}

\author{
Dini Alfiani Maisya \\ Program Studi S1 Ekonomi Islam Fakultas Ekonomi dan Bisnis Universitas Airlangga \\ Email: dini.maisya21@gmail.com \\ Moh. Qudsi Fauzy \\ Departemen Ekonomi Syariah-Fakultas Ekonomi dan Bisnis-Universitas Airlangga \\ Email : qudsifauzy1@gmail.com
}

\begin{abstract}
:
Corporate Social Responsibility (CSR) policy is a company duty in the form of awareness toward environment, considering they grow and develop in the midst of society which may cause externality due to their production. Corporate Social Responsibility (CSR) is a company commitment to contribute in the sustainable economic development with regard to social responsibility and emphasize to the stability of economic, social, and environment aspects.

The result of this research shows that PT. Semen Indonesia has implemented Corporate Social Responsibility Policies in environment sector and conform to Islam economic provision. From some indicators, PT. Semen Indonesia has implemented Corporate Social Responsibility (CSR) with equitable and benefit principle, but from charity and mandate indicators, PT Semen Indonesia has not fully comply in term of implementation.
\end{abstract}

\section{Keywords: CSR, implementation of policies, Islamic CSR}

\section{PENDAHULUAN}

Perkembangan industri dimulai pada awal abad 19 yang dibawa oleh kolonial dengan mendirikan pabrik-pabrik gula yang merupakan langkah awal dalam menjajaki proses bertumbuhnya industri di Indonesia. Berdirinya pabrik gula merupakan pertanda masuknya dan dikenalnya proses industrialisasi dengan menggunakan mesin sebagai alat produksi yang berskala besar.

Di satu sisi, sektor industri atau perusahaan-perusahaan yang berskala besar telah mampu memberikan kontribusi terhadap pertumbuhan ekonomi nasional. Di sisi lain eksploitasieksploitasi terhadap sumber daya alam yang dilakukan oleh perusahaanperusahaan pun semakin marak. Degradasi lingkungan yang cukup parah merupakan dampak utamanya.
Mengenai pengelolaan lingkungan yang benar, diperlukan wawasan mengenai pembangunan sisi ekologi untuk pembangunan berkelanjutan. Pesatnya pertumbuhan ekonomi sektor industri sebagai tulang punggungnya selalu diimbangi dengan pesatnya degradasi mutu lingkungan. Makin pesat pertumbuhan sektor industri hampir selalu mengakibatkan anjloknya mutu lingkungan. Perkembangan industri apapun selalu disertai studi kelayakan (feasibility study) yang meliputi Analisis Menganai Dampak Lingkungan (Amdal).

Saat ini, perusahaan mempunyai tambahan kewajiban yaitu melaksanakan Corporate Social Responsibility (CSR) atau tanggung jawab sosial sesuai yang tercantum pada pasal 74 UndangUndang Republik Indonesia Nomor 40 1) Jurnal ini merupakan bagian dari skripsi dari Dini Alfiani Maisya, NIM : 041211431003, yang diuji pada 23 Mei 2016 
Tahun 2007 tentang Perseroan Terbatas. Undang-Undang ini telah disahkan pemerintah, sehingga pemerintah berharap semua perusahaan yang beroperasi di Indonesia melaksanakan amanat yang tertuang dalam UndangUndang tersebut.

Perkembangan pelaksanaan CSR di Indonesia ditandai, sudah banyak perusahaan mengimplementasikan CSR. Perusahaan semakin banyak menerapkan CSR baik dalam bentuk amal (charity) maupun pembedayaan (enpowerment). Setidaknya bisa dilihat dari gencarnya publikasi berkait dengan implementasi CSR di media cetak dan elektronik.

Penerapan CSR di Indonesia semakin meningkat baik dalam kuantitas maupun kualitas. Selain keragaman kegiatan dan pengelolaannya semakin bervariasi, dilihat dari kontribusi finansial, jumlahnya semakin besar.

Penelitian PIRAC pada tahun 2001 menunjukkan bahwa dana CSR di Indonesia mencapai lebih dari 115 miliar rupiah atau sekitar 11.5 juta dollar AS dari 180 perusahaan yang dibelanjakan untuk 279 kegiatan sosial yang terekam oleh media massa (Saidi, 2004: 64).

Tanggung jawab terkait dengan hak dan kewajiban, yang pada akhirnya dapat menimbulkan dua bentuk kesadaran: Pertama, kesadaran yang muncul dari hati nurani seseorang yang sering disebut dengan etika dan moral. Kedua, kesadaran hukum yang bersifat paksaan karena harus memenuhi tuntutan-tuntutan yang diiringi sanksi hukum.
Dalam pandangan syariah Islam, segala aktifitas bisnis dimaksudkan sebagai bagian dari pengabdian kepada Allah SWT sebagai wujud syukur nikmat atas Rahman Rahim Allah untuk Fastabiqul Khairat. Manusia sebagai mahkluk Allah yang paling sempurna, dilengkapai dengan jiwa yang memungkinkan ia dapat mencapai tingkat spiritualitas yang mulia. Memperoleh kedudukan sebagai leader (khalifah), pemimpin dibumi ini. Seperti firman Allah SWT dalam AI-Quran Surat Al Baqarah ayat 30:

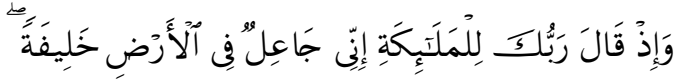

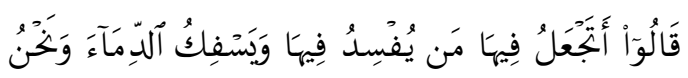

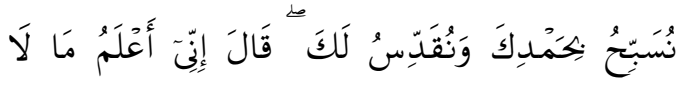

$$
\begin{aligned}
& \text { تَعَلَمَونَ }
\end{aligned}
$$

waiż qata rabbuka lilmalaîkati innījatilun fil ardi khalifah(tan), qatu ataj'alu fiiha' man-yufsidu fiiha wayasfikud dima(a)., wanahnu nusabbihu bihamdika wanuqaddisu lak(a), qata inni a'lamu ma`la'ta'lamun(a).

"Ingatlah ketika Tuhanmu berfirman kepada para Malaikat: "Sesungguhnya AkU hendak menjadikan seorang khalifah di muka bumi." Mereka berkata: "Mengapa Engkau hendak menjadikan (khalifah) di bumi itu orang yang akan membuat kerusakan padanya dan menumpahkan darah, padahal kami senantiasa bertasbih dengan memuji Engkau dan mensucikan Engkau?" Tuhan berfirman: "Sesungguhnya Aku mengetahui apa yang tidak kamu ketahui." (DEPAG, 2014)

Mengacu pada firman Allah yang mengatakan bahwa manusia sebagai leader, khalifah, atau pemimpin dimuka bumi ini, manusia dituntut untuk dapat memimpin dunia dengan didasari hati 
nurani dan ajaran-ajaran llahiyah yang luhur. Manusia tidak boleh memimpin hanya berdasarkan pertimbangan logika dan emosi semata, apalagi demi mengejar kepentingan pribadi dan kelompoknya tanpa memperhatikan kepentingan lingkungan dan masyarakat banyak. Dalam hal ini CSR perusahaan merupakan salah satu wujud kepedulian dalam membangun lingkungan sekitar untuk meningkatkan mutu hidup yang lebih baik dan lebih sejahtera.

Konsep etika dalam bisnis Islam sendiri telah dicontohkan oleh karakteristik Nabi Muhammad SAW., sebagai pedagang dimana selain dedikasi dan keuletannya Nabi SAW juga memiliki sifat shidia, fathanah, amanah dan tabligh ditambah lagi dengan istiqoma (Wahyudi, 2010).

Kaitannya dengan tanggung jawab sosial perusahaan, Sayyid Qutb menjelaskan bahwa Islam mempunyai prinsip pertanggung jawaban yang seimbang dalam segala bentuk dan ruang lingkupnya. Antara jiwa dan raga, antara individu dan keluarga, antara individu dan sosial dan antara suatu masyarakat dengan masyarakat yang lain.

Tanggungjawab sosial merujuk pada kewajiban-kewajiban sebuah perusahaan untuk melindungi dan memberi kontribusi kepada masyarakat dimana perusahaan itu berada (Hidayat, 2013).

Salah satu BUMN yang dituntut untuk melaksanakan CSR adalah PT. Semen Indonesia. PT. Semen Indonesia (Persero) Tbk adalah produsen semen yang terbesar di Indonesia. Pada tanggal 20 Desember 2012, PT. Semen Indonesia
(Persero) Tbk resmi berganti nama dari sebelumnya bernama PT. Semen Gresik (Persero) Tbk.

PT. Semen Indonesia (Persero) berhasil mendapatkan penghargaan Best Disclosure and Transparency pada ajang IICD CG Conference and Awards 2012. Perusahaan menerima penghargaan rintisan teknologi dan lingkungan hijau 2012. Perusahaan berhasil mendapatkan proper peringkat emas dari Kementrian Negara Lingkungan Hidup. Dimana hal ini menunjukkan usaha perusahaan dalam upaya membangun lingkungan perusahaan yang berwawasan hijau dan sebagai bentuk kepedulian perusahaan terhadap kualitas lingkungan. Selain itu Perseroan juga mendapatkan penghargaan Green Industri level 5 tahun 2012 dari Kementerian Perindustrian. Berbagai penghargaan yang diterima oleh Perusahaan dibidang lingkungan menunjukkan semakin mengukuhkan bahwa PT. Semen Gresik merupakan perusahaan semen yang peduli terhadap kelestarian lingkungan.

Dalam kurun waktu lima tahun (2009-2013) PT. Semen Indonesia telah menjalankan beberapa program sosial sebagai komitmenya melaksanakan bisnis yang berkelanjutan dan pemenuhan aspek-aspek dalam Dokumen Analisis Mengenai Dampak Lingkungan (AMDAL). Untuk lima tahun berikutnya, PT. Semen Indonesia telah memiliki Community Investment Program (CIP) 2014-2018, yang mengacu pada ketentuan-ketentuan 
Maisya, et al/Jurnal Ekonomi Syariah Teori dan Terapan Vol. 3 No. 9 September 2016: 744-757; IMPLEMENTASI ISLAMIC CORPORATE SOCIAL RESPONSIBILITY PT. SEMEN INDONESIA

terbaru di tingkat nasional terkait dengan kesejahteraan sosial, layanan publik dan tanggung jawab sosial dan lingkungan.

Mengingat perusahaan tumbuh dan berkembang di tengah-tengah masyarakat dengan menimbulkan eksternalitas atas kegiatan produksinya, maka perusahaan juga perlu menyadari bahwa perusahaan terdiri dari para individu yang terlibat di dalamnya, yakni pemilik dan karyawanya. Sehingga perusahaan seharusnya lebih peka dan tidak hanya memikirkan keuntungan finansial saja, melainkan harus memiliki kepekaan dan kepedulian terhadap publik, khususnya masyarakat beserta lingkungan di sekitar perusahaan. Diakui atau tidak, dibalik maju dan berkembangnya pesatnya suatu perusahaan selalu disertai dengan peran masyarakat dan lingkungan. Karena masyarakat dan lingkungan adalah sumberdaya yang dimiliki dan direproduksi oleh perusahaan.

\section{LANDASAN TEORI}

Eksternalitas yaitu dampak-dampak tidak terkompensasi dari tindakan seseorang terhadap kesejahteraan orang lain yang terlibat. Eksternalitas mucul ketika seseorang terlibat dalam kegiatan mempengaruhi kesejahteraan orang lain yang tidak membayar atau menerima kompensasi atas dampak tersebut (Mankiw, 2004: 21).

Corporate Social Responsibility adalah komitmen perusahaan untuk meningkatkan kesejahteraan komunitas melalui praktik bisnis yang baik dan mengkontribusikan sebagian sumber daya perusahaan (Kotler \& Nancy, 2005: 4).
Selain BUMN, saat ini Perseroan Terbatas (PT) yang mengelola atau operasionalnya terkait dengan Sumber Daya Alam (SDA) diwajibkan melaksanakan program CSR, karena telah diatur dalam Undang-Undang Perseroan Terbatas No 40 Tahun 2007.

Dalam pasal 74 diatur bahwa:

1. Perseroan yang menjalankan kegiatan usahanya di bidang dan/atau berkaitan dengan sumber daya alam, wajib melakukan Tanggung Jawab Sosial dan Lingkungan,

2. Tanggung Jawab Sosial dan Lingkungan sebagaimana dimaksud ayat (1) merupakan kewajiban Perseroan yang dianggarkan dan diperhitugkan sebagai biaya Perseroan yang pelaksanaannya dilakukan dengan memperhatikan kepatuhan dan kewajaran,

3. Perseroan yang tidak melaksanakan kewajiban sebagaimana dimaksud pada ayat (1) dikenai sanksi sesuai dengna ketentuan peraturan perundang-undangan,

4. Ketentuan lebih lanjut mengenai Tanggung Jawab Sosial dan Lingkungan diatur dengan Peraturan Pemerintah.

Mengacu pada Keputusan Menteri BUMN Nomor Per-05/MBU/2007 pelaksanaan tanggungjawab sosial dikelompokkan menjadi dua, yaitu Program Kemitraan dan Bina Lingkungan. Program Kemitraan adalah program untuk 
meningkatkan kemampuan usaha kecil dalm bentuk pinjaman baik untuk modal usaha maupun pembelian perangkat penunjang produksi agar usaha kecil menjadi tangguh dan madiri. Sementara Program Bina Lingkungan adalah program pemberdayaan kondisi sosial masyarakat untuk tujuan yang memberikan manfaat kepada masyarakat di wilayah usaha BUMN yang bersangkutan.

Menurut Djakfar (2007: 12), implementasi CSR dalam Islam secara rinci harus memenuhi beberapa unsur yang menjadikannya ruh sehingga dapat membedakan CSR dalam perspektif Islam dengan CSR secara universal yaitu:

1. Al-Adl

Sifat keseimbangan atau keadilan dalam bisnis adalah ketika korporat mampu menempatkan segala sesuatu pada tempatnya. Dalam beraktifitas di dunia bisnis, Islam mengharuskan berbuat adil yang diarahkan kepada hak orang lain, hak lingkungan sosial, hak alam semesta.

Islam juga melarang segala bentuk penipuan, gharar (spekulasi), najsi (iklan palsu), intikar (menimbun barang) yang akan merugian pihak lain. Islam menuntut keseimbangan/kesejajaran antara kepentingan diri dan kepentingan orang lain, antara kepentingan si kaya dan si miskin, antara hak pembeli dan hak penjual dan lain sebagainya. Artinya hendaknya sumberdaya ekonomi itu tidak hanya terakumulasi pada kalangan orang atau kelompok tertentu semata (Djakfar, 2007: 12).

2. Al-Ihsan

Islam hanya memerintahkan dan menganjurkan perbuatan yang baik bagi kemanusiaan, agar amal yang dilakukan manusia dapat memberi nilai tambah dan mengangkat derajat manusia baik individu maupun kelompok. Implementasi CSR dengan semangat Ihsan akan dimiliki ketika individu atau kelompok melakukan kontribusi dengan semangat ibadah dan berbuat karena atas ridho Allah SWT.

Ihsan adalah melakukan perbuatan baik, tanpa adanya kewajiban tertentu untuk melakukan hal tersebut. Ihsan adalah beauty dan perfection dalam sistem sosial. Bisnis yang dilandasi unsur ihsan dimaksudkan sebagai proses niat, sikap dan perilaku yang baik, transaksi yang baik, serta berupaya memberikan keuntungan lebih kepada stakeholders. Jika diukur dari ajaran Ihsan, perbuatan CSR tidak perlu mengharapkan imbalan dari orang yang dibantu. Apalagi yang dibantu adalah masyarakat miskin yang serba terbatas dalam segala aspek kehidupan (Djakfar, 2007: 12).

3. Manfaat

Pada dasarnya, perusahaan telah memberikan manfaat terkait operasional yang bergerak dalam bidang produksi yang sangat dibutuhkan masyarakat. Konsep manfaat dalam Corporate Social Responsibility (CSR), lebih dari aktivitas ekonomi. Perusahaan sudah seharusnya memberikan manfaat yang lebih luas dan tidak statis misalnya terkait bentuk philanthropi dalam berbagai aspek sosial seperti pendidikan, kesehatan, pemberdayaan kaum marginal, pelestarian lingkungan.

4. Amanah

Perusahaan yang menerapkan Corporate Social Responsibility (CSR), harus memahami dan menjaga Amanah dari masyarakat yang secara otomatis terbebani di pundaknya. Misalnya menciptakan produk yang berkualitas, serta menghindari perbuatan tidak terpuji dalam setiap aktivitas bisnis. Amanah dalam perusahaan dapat dilakukan dengan transparansi yang jujur kepada konsumen, serta Amanah dalam pembayaran pajak, pembayaran karyawan, dll. Amanah dalam skala makro dapat direalisasikan dengan melaksanakan perbaikan sosial dan 
Maisya, et al/Jurnal Ekonomi Syariah Teori dan Terapan Vol. 3 No. 9 September 2016: 744-757; IMPLEMENTASI ISLAMIC CORPORATE SOCIAL RESPONSIBILITY PT. SEMEN INDONESIA

menjaga keseimbangan lingkungan (Djakfar, 2007: 12).

Pelaku usaha/pihak perusahaan

harus memiliki Amanah dengan menampilkan sikap keterbukaan, kejujuran, pelayanan yang optimal. Dalam penerapan CSR, Amanah bisa dilihat dari bagaimana suatu perusahaan terbuka dalam melaporkan kegiatan atau aktivitas CSR yang telah dilaksanakan.

Dalam melakukan praktik CSR tidak bisa terlepas kaitannya dengan dengan istilah stakeholders atau pemangku kepentingan, karena mempengaruhi dan di pengaruhi terkait dengan terpenuhinya kebutuhan masingmasing.

Definisi stakeholder adalah kelompokkelompok yang mempengaruhi dan/atau dipengaruhi oleh organisasi tersebut sebagai dampak dari aktivitasaktivitasnya (Tanari, 2009: 17).

Stakeholders dalam entitas

perusahaan terbagi ke dalam tujuh jenis, yaitu: pelanggan, masyarakat, karyawan, pemegang saham, lingkungan, Lembaga Swadaya Masyarakat (LSM) dan pemerintah.

Dalam Konteks penerapan CSR, stakeholders wajib di rangkul dan dilibatkan baik dalam tahap perencanaan, implementasi dan evaluasi. Jika salah satu stakeholders tidak terlibat atau mendapat manfaat dari perusahaan, maka akan berpotensi menjadi masalah bagi keberlanjutan perusahaan.

\section{METODE PENELITIAN}

Jenis penelitian ini adalah deskriptif. Penelitian ini menggunakan tiga metode untuk mengumpulkan data, yaitu observasi, wawancara, dan dokumentasi. Lokasi penelitian ini adalah Kabupaten Tuban. Dalam penelitian ini, peneliti menggunakan data kualitatif. Sedangkan sumber data yang digunakan dalam penelitian ini ada 2, yaitu primer dan sekunder.

\section{Teknik Pengumpulan Data}

Suharsimi Arikunto (2002: 136), berpendapat bahwa

"metode penelitian adalah berbagai cara yang digunakan peneliti dalam mengumpulkan data penelitiannya".

1. Wawancara

Dalam penelitian ini, wawancara dilakukan kepada pihak-pihak terkait, yaitu industri PT. Semen Indonesia dan masyarakat penerima bantuan dana CSR.

2. Dokumentasi

Dalam penelitian ini, contoh hasil dokumentasi adalah catatan, transkip, buku, dokumen, peraturan, surat keputusan, edaran, dan sebagainya akan sangat berpengaruh dalam pemaparan atau menjelaskan kejadian sebenarnya.

\section{Teknik Analisis Data}

Teknik analisis data yang digunakan dalam penelitian ini adalah menggunakan langkah-langkah seperti yang dikemukakan oleh Bungin (2003: 70), yaitu sebagai berikut:

1. Pengumpulan data merupakan bagian integral dari kegiatan analisis data. Kegiatan 
pengumpulan data pada penelitian ini adalah dengan menggunakan wawancara dan studi dokumentasi.

2. Reduksi data diartikan sebagai proses pemilihan, pemusatan perhatian pada penyederhanaan, pengabtrakan dan transformasi data kasar yang muncul dari catatancatatan tertulis di lapangan yaitu suatu bentuk analasis yang menajamkan, menggolongkan, mengarahkan dan memilih data dengan cara sedemikian rupa sehingga kesimpulan-kesimpulan finalnya dapat ditarik dan diverifikasikan.

3. Penyajian Data, di artikan sebagai sekumpulan informasi yang tersusun yang memberi kemungkinan adanya penarikan kesimpulan dan pengambilan tindakan. Dalam penelitian ini, data yang telah mengalami penyederhanaan dan penggolongan tersebut disajikan sedemikian rupa sehingga mudah terbaca yang nantinya di gunakan untuk menjawab permasalahan penelitian.

4. Penarikan kesimpulan, memberikan kesimpulan atas hasil pembahasan yang sesuai bidang permasalahan.

\section{Uji Validitas Data}

Dalam memenuhi validitas data penelitian ini dilakukan triangulasi dengan sumber. Menurut Patton, triangulasi dengan sumber berarti membandingkan dan mengecek balik derajat kepercayaan suatu informasi yang diperoleh melalui waktu dan alat yang berbeda dalam penelitian kualitatif (Moleong, 2007: 29).

\section{HASIL DAN PEMBAHASAN}

\section{Program Bina Lingkungan PT. Semen Indonesia}

Program Bina Lingkungan adalah sarana untuk menjaga keseimbangan lingkungan dengan perusahaan pasca kegiatan produksi maupun yang sedang produksi, kalau yang pasca produksi minimal sama dengan sebelum ada penambangan. Program Bina Lingkungan meliputi pembinaan pemberdayaan masyarakat melalui pemberian bantuan sarana umum, keagamaan, pendidikan, kesejahteraan sosial, kesehatan dan bantuan lainnya untuk pembangunan infrastruktur. Perusahaan memiliki rancana strategis lima tahunan (2011-2015) dan rencana tahunan yang disusun berdasarkan hasil social mapping dan melibatkan masyarakat/pemerintah melalui Musrenbangda (Musyawarah Rencana Pembangunan Daerah) dan Musrengbangdes (Musyawarah Rencana Pembangunan Desa) termasuk juga didalam proses evaluasi pelaksanaannya. Dalam rangka mewujudkan program CSR, bina lingkungan melakukan beberapa tindakan community development dan pemberian charity kepada masyarakat sekitar pabrik. Bina Lingkungan melakukan beberapa langkah strategis dalam mengimplementasikan CSR, seperti pemetaan lingkungan dan masyarakat di 
Maisya, et al/Jurnal Ekonomi Syariah Teori dan Terapan Vol. 3 No. 9 September 2016: 744-757; IMPLEMENTASI ISLAMIC CORPORATE SOCIAL RESPONSIBILITY PT. SEMEN INDONESIA

sekitar perusahaan, menetapkan pola, area dan jenis bina lingkungan, melibatkan peran serta masyarakat yang dibina, evaluasi efektivitas dan multieffect atas pembinaan dan sistem pembinaan yang berkelanjutan.

Pelaksanaan tanggung jawab sosial perusahaan/ CSR dari PT. Semen Indonesia berupa program dan kegiatan yang mengusung misi dan fokus yang berbeda-beda. Dalam lima tahun terakhir (2009-2013) PT. Semen Indonesia telah menjalankan beberapa program sosial sebagai komitmennya melaksanakan bisnis yang berkelanjutan dan pemenuhan aspek-aspek dalam Dokumen Analisis Mengenai Dampak Lingkungan ( $A M D A L)$. Untuk lima tahun berikutnya, PT. Semen Indonesia telah memiliki Community Investment Program (CIP) 2014-1018 yang mengacu pada ketentuan-ketentuan terbaru di tingkat nasional terkait dengan kesejahteraan sosial, layanan publik dan tanggungjawab sosial dan lingkungan. Program CIP akan mencakup pada program induk yaitu Semen Indonesia Bersinergi (Bersama Semen Indonesia Cerdaskan Negeri), dengan empat pilar utama, yakni Semen Indonesia Cerdas, Semen Indonesia Prima, Semen Indonesia Lestari dan Semen Indonesia Peduli.

Pelaksanaan CSR Bidang Lingkungan PT. Semen Indonesia yang Terlaksana pada Tahun 2015

Dalam kurun waktu enam puluh tahun PT. Semen Indonesia telah melakukan berbagai program dan kegiatan sebagai tanggung jawab sosial perusahaan (Corporate Social Responsibility/ CSR). Pelaksanaan tanggung jawab sosial perusahaan/ CSR PT. Semen Indonesia dilaksanakan oleh peusahaan PT. Semen Indonesia sendiri tanpa melalui perantara lembaga atau yayasan. Hal ini merupakan upaya serius dari sejak awal didirikannya PT. Semen Indonesia untuk menjadi perusahaan yang turut berperan serta dalam memajukan bangsa dengan cara meningkatkan kualitas sumber daya manusia dan mempertahankan kelestarian sumber daya alam Indonesia. Berikut adalah data program CSR PT. Semen Indonesia yang telah terlaksana di Gresik pada tahun 2015:

1. Semen Indonesia Cerdas Perusahaan mewujudkan pilar SI Cerdas bagi masyarakat dengan berbagai program/kegiayan yang ditujukan sebagai dukungan terhadap program Pemerintah untuk mencerdaskan anak bangsa. Nilai inti dari program SI cerdas adalah menghadirkan pendidikan berkualitas dan pengembangan life skill \& soft skill masyarakat untuk menjadi mandiri. Beberapa kegiatan Semen Indonesia Cerdas yang telah terlaksana di wilayah Gresik pada tahun 2015 adalah bantuan 200 buku untuk perpustakaan Rumah Pelangi Gresik, bantuan laptop \& LCD proyektor di TPQ An-Nuur, bantuan alat permainan edukatif untuk SPS TP 
Maisya, et al/Jurnal Ekonomi Syariah Teori dan Terapan Vol. 3 No. 9 September 2016: 744-757; IMPLEMENTASI ISLAMIC CORPORATE SOCIAL RESPONSIBILITY PT. SEMEN INDONESIA

Permata Bunda kel. Sidomukti, Kec. Kebomas Gresik.

\section{Semen Indonesia Prima}

Pilar SI Prima diwujudkan melalui peran serta perusahaan pada aktivitas pemasaran yang direalisasikan dalam bentuk Corpotate Social Responsibility. Nilai inti dari program SI Prima adalah memberikan kemudahan akses sarana umum bagi masyarakat sekitar perusahaan. Beberapa kegiatan Semen Indonesia Prima yang telah terlaksana di wilayah Gresik pada tahun 2015 adalah sarana prasarana lingkungan sehat Kelurahan Gending, pembangunan sarana wudhu \& Toilet MI Ma'arif Nurul Ulum, pembangunan Musholah Al Muhajirin.

3. Semen Indonesia Lestari

SI Lestari adalah program yang berorientasi pada kelestarian alam dan keanekaragaman hayati. PT Semen Indonesia (Persero) Tbk bersama entitas anak usaha berupaya agar proses penambangan bahan baku, energi maupun produksi semen dilakukan dengan tetap memperhatikan kelestarian lingkungan. Beberapa kegiatan Semen Indonesia Peduli yang telah terlaksana di wilayah Gresik pada tahun 2015 adalah Penanaman 10.000 pohon Mangrove dan santunan 70 Anak Yatim di Ujungpangkah, penghijauan di RT 02/ RW 03 Tlogobendung, pembangunan bank sampah dan lantai keramik di Kel. Tlogopatut.

4. Semen Indonesia Peduli
Program yang berorientasi pada siaga bencana dan pengentasan kemiskinan, diwujudkan melalui pendekatan terhadap masyarakat. Pendekatan yang dilakukan adalah dengan berbagai program/kegiatan pelayanan, pembinaan hubungan, dan pemberdayaan masyarakat. Sasaran dari pelaksanaan program/kegiatan adalah pengembangan lingkungan sosial dan ekonomi, yang diharapkan meningkatkan kesejahteraan mereka sesuai Indeks Pembangunan Manusia (IPM) serta Millenium Development Goals (MDGs). Beberapa kegiatan Semen Indonesia Peduli yang telah terlaksana di wilayah Gresik pada tahun 2015 adalah kegiatan khitanan massal dan Santunan Anak Yatim Majelis Ulama Indonesia Kabupaten Gresik, KKN BBM 52 UNAIR, bantuan 1000 sembako murah di desa Bulangan Kec. Dukun, Kab. Gresik, bantuan keranda mayat untuk Sinoman Kajen Tengah.

\section{PEMBAHASAN}

Penerapan Keadilan dalam Kebijakan CSR Bidang Lingkungan PT. Semen Indonesia

Berdasarkan hasil wawancara dengan pihak bina lingkungan PT. Semen Indonesia mengenai keadilan dalam penerapan kebijakan CSR bidang lingkungandapat diperoleh informasi bahwa program-program tanggung jawab jawab sosial dan lingkungan yang diterapkan pada daerah Gresik di mana pabrik sudah tidak aktif beroperasi lagi atau dapat dikatakan penambangan sudah selesai dilakukan dan kini 
perusahaan lebih fokus pada recovery lingkungan.dan daerah Rembang dimana di daerah ini pebrik masih dalam tahap pembangunan memiliki konsep yang sama, namun pada penerapannya berbeda karena perbedaan pola masyaraktnya. Untuk program CSR di daerah Gresik sebagian besar berupa charity karena mayoritas masyarakat Gresik yang sudah maju dan memiliki kepentingan masing-masing, sedangkan untuk daerah Rembang dan Tuban program CSR yang diberikan berupa pelatihan karena masyarakatnya yang homogen sehingga akan mudah terpecah apabila tidak diberikan pelatihan. Selain itu keadilan disini juga bisa dilihat dari program-program yang telah terlaksana. Dari program-program CSR bina lingkungan yang telah terlaksana tersebut keseimbangan sosial dan keseimbangan alam terjaga bersamaan. Hal ini dibuktikan dengan tidak adanya demo masyarakat kepada PT. Semen Indonesia. Informan sempat mengatakan bahwa salah satu ukuran keberhasilan program CSR ini adalah tidak adanya demo masyarakat. Sedangkan keseimbangan alam dibuktikan dengan program penghijauan yang dilakukan di sekitar pabrik sebagai upaya menjaga alam dan keberhasilan perusahaan dalam mengurangi emisi gas.

Sedangkan dari hasil wawancara dengan pihak penerima dana atau bantuan CSR mengenai keadilan dari penerapan kebijakan CSR adalah di buktikan dengan penempatan bantuan yang tepat sesuai dengan kebutuhan. Karena adil juga bisa di artikan dengan menempatkan sesuatu pada tempatnya. Dari hasil wawancara dengan pengurus mushola dalam pembangunan mushola PT. Semen Indonesia memberikan bantuan berupa semen untuk membantu pembangunan mushola. Sedangkan untuk perpustakaan PT. Semen Indonesia memberikan bantuan berupa buku bacaan. Hal ini membuktikan bahwa PT. Semen Indonesia telah menempatkan sesuai dengan kebutuhan masyarakat sehingga bantuan yang diberikan dapat berguna.

Berdasarkan informasi yang telah dijelaskan dari paragraph sebelumnya dapat diperoleh suatu gambaran bahwa secara keseluruhan PT. Semen Indonesia menerapkan prinsip keadilan dalam penerapan kebijakan CSR bidang lingkungan karena PT. Semen Indonesia dapat menempatkan sesuai dengan tempatnya seperti menentukan programprogram CSR bidang lingkungan yang sesuai dengan kebutuhan masyarakat.

Penerapan Ihsan dalam Kebijakan CSR Bidang Lingkungan PT. Semen Indonesia

Berdasarkan hasil wawancara dengan pihak bina lingkungan PT. Semen Indonesia mengenai prinsip ajaran ihsan dalam penerapan kebijakan CSR bidang lingkungandapat diperoleh informasi bahwa PT. Semen Indonesia melakukan program CSR tanpa mengharapkan balasan. Penerapan ihsan pada PT. 
Maisya, et al/Jurnal Ekonomi Syariah Teori dan Terapan Vol. 3 No. 9 September 2016: 744-757; IMPLEMENTASI ISLAMIC CORPORATE SOCIAL RESPONSIBILITY PT. SEMEN INDONESIA

Semen Indonesia terwujud dalam program yang tidak menuntut pada imbalan. Seperti program bina lingkungan yang memberikan bantuan dana untuk pembangunan masjid dan sekolah.

Sedangkan dari hasil wawancara dengan pihak penerima dana atau bantuan CSR mengenai ihsan dalam penerapan kebijakan CSR dapat dibuktikan dengan dengan jawaban dari penerima bantuan CSR bahwa PT. Semen Indonesia tidak mengharapkan imbalan dari bantuan yang telah di berikan, hanya saja pada kegiatan kkn PT. Semen Indonesia meminta untuk mencantuklan logo PT. Semen Indonesia dalam banner.

Berdasarkan informasi yang telah dijelaskan dari paragraph sebelumnya dapat diperoleh suatu gambaran bahwa PT. Semen Indonesia dalam menerapkan prinsip ihsan dalam kebijakan CSR belum sepenuhnya baik dan ikhlas semata-mata karena Allah. Karena PT. Semen Indonesia pernah meminta untuk mencantumkan logo PT. Semen Indonesia dalam kegiatan yang di danai oleh PT. Semen Indonesia. Hal ini menunjukkan bahwa agar masyarakat mengetahui bahwa dalam program yang terlaksana tersebut terdapat bantuan dari PT. Semen Indonesia.

\section{Penerapan Manfaat dalam Kebijakan CSR}

\section{Bidang Lingkungan PT. Semen Indonesia}

Selain menjalankan bisnisnya, PT. Semen Indonesia juga tidak lupa memberikan manfaat kepada elemenelemen yang menunjang bisnis perusahaan sendiri, yaitu karyawan, konsumen dan lingkungan sekitar. Berdasarkan hasil wawancara dengan pihak bina lingkungan PT. Semen Indonesia mengenai manfaat dalam penerapan kebijakan CSR bidang lingkungan dapat diperoleh informasi bahwa dengan adanya program CSR bina lingkungan berupa community development atau comdev PT. Semen Indonesia telah memberikan manfaat beupa pelatihan kepada masyarakat agar bisa di gunakan dalam jangka panjang dan untuk membantu meningkatkan perekonomian masyarakat dengan menerapkan pelatihan yang telah diberikan oleh pihak bina lingkungan PT. Semen Indonesia.

Sedangkan dari hasil wawancara dengan pihak penerima dana atau bantuan CSR mengenai manfaat dalam penerapan kebijakan CSR yaitu mereka mendapatkan banyak sekali manfaat yang di peroleh dengan adanya kebijakan CSR ini, baik manfaat yang di rasakan langsung oleh penerima bantuan maupun yang di rasakan masyarakat lain yang menikmati hasil dari bantuan tersebut. Jadi manfaat yang dirasakan masyarakat tidak hanya berupa hasil produksinya saja berupa semen tetapi juga berupa materi lain yang di berikan oleh PT. Semen Indonesia yang di dapatkan dari hasil produksinya kemudian menghasilkan laba dan laba tersebtlah yang menghasilkan manfaat lain yang 
Maisya, et al/Jurnal Ekonomi Syariah Teori dan Terapan Vol. 3 No. 9 September 2016: 744-757; IMPLEMENTASI ISLAMIC CORPORATE SOCIAL RESPONSIBILITY PT. SEMEN INDONESIA

bisa di berikan kepada masyarakat yang membutuhkan bantuan.

Berdasarkan informasi yang telah dijelaskan dari paragraph sebelumnya dapat diperoleh suatu gambaran bahwa secara keseluruhan PT. Semen Indonesia menerapkan prinsip manfaat dalam penerapan kebijakan CSR.

Penerapan Amanah dalam Kebijakan CSR Bidang Lingkungan PT. Semen Indonesia

Berdasarkan hasil wawancara dengan pihak bina lingkungan PT. Semen Indonesia mengenai amanah dalam penerapan kebijakan CSR bidang lingkungan dapat diperoleh informasi bahwa PT. Semen Indonesia bertanggung jawab atas undang-undang yang dibuat oleh pemerintah sebagai bentuk upaya pemerintah dalam menjaga kelestarian lingkungan. Dalam hasil wawancara disebutkan bagaimana pandangan perusahaan terhadap kebijakan tanggung jawab sosial dan lingkungan, menurut PT. Semen Indonesia CSR adalah tanggung jawab yang harus dilaksanakan oleh perusahaan untuk menjaga hubungan baik antara perusahaan dengan masyarakat.

Sedangkan dari hasil wawancara dengan pihak penerima dana atau bantuan CSR mengenai amanah dalam penerapan kebijakan CSR dapat dilihat dengan monitoring yang dilakukan PT. Semen Indonesia setelah memberikan dana ata bantuan. Monitoring yang dilakukan PT. Semen Indonesia dilakukan untuk mengetahui apakah bantuan yang di berikan bermanfaat atau tidak, kemudian apakah bantuan sudah memenuhi atau sudah sesuai dengan kebutuhan masyarakat.

Namun PT. Semen Indonesia dalam pelaporan kegiatan CSR yang telah terlaksana kurang terbuka terhadap masyarakat. Pelaporan kegiatan CSR hanya ditujukan kepada pihak internal perusahaan atau para stakeholder. Dengan ketidak terbukaan perusahaan terhadap masyarakat mengenai program CSR yang telah terlaksana akan menimbulkan ketidakpercayaan oleh masyarakat.

Berdasarkan informasi yang telah dijelaskan dari paragraph sebelumnya dapat diperoleh suatu gambaran bahwa PT. Semen Indonesia dalam menerapkan kebijakan CSR kurang amanah. Hal ini di buktikan dengan kurangnya keterbukaan pelaporan CSR kepada masyarakat.

\section{SIMPULAN}

1. Penerapan prinsip keadilan PT. Semen Indonesia dalam penerapan kebijakan Corporate Social Responsibilty bidang lingkungan diterapkan dengan cara memberikan bantuan sesuai dengan kebutuhan masyarakat. PT. Semen Indonesia telah berbagi kebaikan dalam bentuk materiil dan non-materiil kepada masyarakat tanpa membedabedakan status, suku, agama dan ras.

2. PT. Semen Indonesia dalam penerapan kebijakan Corporate Social Responsibilty bidang 
lingkungan belum menerapkan prinsip ihsan secara sempurna, karena PT. Semen Indonesia masih mengharapkan sesuatu setelah memberikan bantuan atau di sebut juga dengan imbalan meskipun tidak berupa barang melainkan berupa permintaan untuk menampilkan logo PT. Semen Indonesia pada banner program kerja kkn yang telah di berikan bantuan berupa dana dari PT. Semen Indonesia. Pemurniat niat penerapan kebijakan CSR yang merupakan kesadaran akan tanggungjawab sosial semata-mata menjalankan perintah Allah SWT, dalam praktek masih ada kemungkinan tujuan ganda yaitu sambil promosi dan dengan sengaja memberitakan kepada khalayak bahwa perusahaan telah menjalankan CSR dan bisa mengarah pada perilaku riya.

3. PT. Semen Indonesia dalam penerapan kebijakan Corporate Social Responsibilty bidang lingkungan telah memberikan banyak manfaat tidak hanya dari hasil produksinya saja tetapi memberikan manfaat dari bantuan yang diberikan kepada masyarakat baik manfaat yang dirasakan langsung oleh penerima bantuan atau manfaat yang dirasakan masyarakat sekitar yang ikut serta merasakan hasil dari bantuan yang diberikan PT. Semen Indonesia.
4. PT. Semen Indonesia dalam penerapan kebijakan Corporate Social Responsibilty bidang lingkungan kurang bersifat amanah, karena kurang terbuka kepada masyarakat mengenai pelaporan hasil Corporate Social Responsibilty kepada masyarakat luas hanya terbatas di kalangan sendiri. Sehingga masyarakat tidak dapat mengetahui penerapan CSR PT. Semen Indonesia yang telah terlaksana dapat menggantikan dampak eksternalitas yang di timbulkan dari hasil produksi.

5. Kesesuian penerapan kebijakan Corporate Social Responsibility dengan indikator etika bisnis Islam adalah prinsip manfaat. Islam mengajarkan bahwa sebaik-baik manusia adalah yang memberi manfaat kepada orang lain. Perusahaan memberikan banyak manfaat kepada masyarakat dalam penerapan kebijakan Corporate Social Responsibility baik manfaat jangka panjang maupun jangka pendek.

Saran yang dapat diberikan berdasarkan hasil analisisdalam penelitian ini adalah:

1. Bagi PT. Semen Indonesia (Persero) Tbk

PT. Semen Indonesia hendaknya memurnikan niat dalam penerapan kebijakan CSR sebagai bentuk konsekuensi dari dampak kegiatan perusahaan atas dasar ridho Allah SWT. 
Senatiasa mengevaluasi setiap pelaksanaan CSR supaya kegiatan CSR tepat sasaran dan memberikan banyak manfaat kepada masyarakat. Programprogram CSR diprioritaskan kepada golongan ekonomi lemah melalui program yang bersifat sustainable berbentuk Community Development tidak berbentuk charity yang hanya menimbulkan ketergantungan masyarakat kepada perusahaan. Manajemen perusahaan diharapkan lebih terbuka mengungkapkan kegiatankegiatan yang berhubungan dengan tanggungjawab sosial dan lingkungan perusahaan dalam pelaporan tahunannya.

\section{Bagi Penelitian Selanjutnya}

Penelitian ini masih terdapat banyak kekurangan dan keterbatasan, sehingga bagi penelitian selanjutnya diharapkan dapat meneliti topik yang sama dengan objek atau prinsip yang berbeda. Hasil dari penelitian selanjutnya dapat memberikan sumbangsih kepada perusahaan lainnya untuk mempraktekkan konsep Corporate Social Responsibility sesuai dengan prinsip ekonomi Islam.

\section{Daftar Pustaka}

Arikunto, Suharsimi. 2002. Prosedur Penelitian Suatu Pendekatan Praktik. Jakarta: PT. Rineka Cipta

Bungin, Burhan. 2003. Analisis Data Penelitian Kualitatif . Jakarta: PT Raja Grafindo Persada.

Departemen Agama RI. 2014. Al-Qur'an dan Terjemahannya. Surabaya: Mahkota

Djakfar, Muhammad. 2007. Etika Bisnis dalam Perspektif Islam. Malang: UIN Malang Press.

Hidayat, H. 2013. Tanggung Jawab Sosial Perusahaan dalam Islam.

http://mherry.blogspot.com/2013/04/tang gung-jawab-sosial perusahaandalam.html). diakses 20 November 2015

Kotler, Philip and Nancy Lee. 2005. Corporate Social Responsibility. Amerika: John Wiley\&Sons, Inc.

Mankiw, Gregory. 2004. Principles of Macroeconomics. $3^{\text {th }}$ edition. AS: South Western of Thomson Learning.

Moeleong, Lexy. 2007, Metode Penelitian Kualitatif. Bandung: PT. Remaja Rosdakaya.

Saidi dan Abidin, 2004. Corporate Social Responsibility, Alternatif bagi Pembangunan Indonesia. Jakarta: ICSD.

Tanari Adrianus. 2009. Materi Training CSR as per ISO 2006. Jakarta: Valueconsult

UU Peraturan Pemerintah No. 40 Tahun 2007 tentang "Perseroan Terbatas"

Wahyudi, A.I. 2010. Pandangan Islam Tentang CSR.

(http://kseiprogres.blogspot.com/2010/01/ pandangan-islam-tentang-csr.html diakses 02 Oktober 2015 